Spring 2002

\title{
Liberal Ideals and Political Feasibility: Guest-Worker Programs as Second-Best Policies
}

Howard F. Chang

Follow this and additional works at: https://scholarship.law.unc.edu/ncilj

\section{Recommended Citation}

Howard F. Chang, Liberal Ideals and Political Feasibility: Guest-Worker Programs as Second-Best Policies, 27 N.C. J. INT'L L. 465 (2001).

Available at: https://scholarship.law.unc.edu/ncilj/vol27/iss3/4

This Comments is brought to you for free and open access by Carolina Law Scholarship Repository. It has been accepted for inclusion in North Carolina Journal of International Law by an authorized editor of Carolina Law Scholarship Repository. For more information, please contact law_repository@unc.edu. 


\section{Liberal Ideals and Political Feasibility: Guest-Worker Programs as Second-Best}

Policies

\section{Cover Page Footnote}

International Law; Commercial Law; Law 


\title{
Liberal Ideals and Political Feasibility: Guest-Worker Programs as Second-Best Policies
}

\author{
Howard F. Chang*
}

A liberalized guest-worker program appeared to be a priority on the political agenda while President George W. Bush weighed proposals to expand access to employment-based visas ${ }^{1}$ until terrorist attacks placed these plans on hold. ${ }^{2}$ Support from both labor unions and business interests may make liberalizing reforms politically feasible in the near future, ${ }^{3}$ as the Bush administration, with the support of Democrats in Congress, has recently resumed negotiations with Mexico on immigration policy. ${ }^{4}$ This dramatic reversal of the overwhelmingly restrictionist politics of recent years is a welcome development, as considerations of not only national economic welfare but also social justice militate in favor of liberalizing reforms.

In the case of skilled aliens, the United States can lift

* Professor of Law, University of Pennsylvania Law School; Visiting Professor of Law, University of Michigan Law School. Ph.D., 1992, MIT; J.D., 1987, Harvard; M.P.A., 1985, Princeton; A.B., 1982, Harvard. I would like to thank the Symposium participants at the University of North Carolina School of Law for their helpful comments.

1 See Dan Eggen \& Helen Dewar, Bush Weighing Plan for Mexican Guest Workers, WASH. POST, July 25, 2001, at A3; Eric Schmitt, Bush Panel Backs Legalizing Status of Some Migrants, N.Y. TIMES, July 24, 2001, at A1; Eric Schmitt, Bush Says Plan for Immigrants Could Expand, N.Y. TIMES, July 27, 2001, at A1; Eric Schmitt, U.S.Mexico Talks Produce Agreement on Immigration Policy, N.Y. TIMES, Aug. 10, 2001, at A4.

2 See Alfredo Corchado, Immigration Talks Between U.S., Mexico on Hold, Dallas Morning News, Sept. 19, 2001, at 5A; Mike Dorning, Mexico Border Issue on Hold, CHI. TRIB., Sept. 21, 2001, at 16; Greg Miller \& Nick Anderson, Mood Swiftly Changes on Immigration, L.A. TimEs, Sept. 18, 2001, at A12; James Sterngold, Legal Residency Hopes of Millions Dashed, N.Y. TIMES, Oct. 7, 2001, at A33.

3 See Thomas B. Edsall \& Cheryl W. Thompson, Alliance Forms on Immigrant Policies: Business, Church, Labor Groups Unite on Liberalization, WASH. Post, Aug. 7, 2001, at A1.

4 See Mary Jordan \& Kevin Sullivan, U.S. and Mexico to Resume Talks on Immigration Policy, WASH. Post, Nov. 15, 2001, at A40; Ginger Thompson, Top Democrats Politick Through Rural Mexico, N.Y. Times, Nov. 19, 2001, at A12. 
restrictions on the employment of aliens consistent with the national interest by liberalizing access to employment-based immigrant visas for skilled workers. ${ }^{5}$ Skilled workers tend to have higher incomes and pay more in taxes than they cost in terms of public benefits. The empirical evidence confirms that educated immigrants will on average have a net positive effect on natives, taking into account their effects on the public treasury. ${ }^{6}$

In the case of unskilled aliens, however, the optimal policyfrom the perspective of the interests of natives-departs significantly from the policy prescribed by liberal ideals. From the narrow perspective of the economic interests of natives, temporary worker visas may be an optimal response to fiscal concerns regarding alien access to public benefits. ${ }^{7}$ Through guest-worker programs, natives enjoy the benefits of unskilled alien workers in the labor market but do not bear the fiscal burden of providing the full set of public benefits that these workers would receive if they had ready access to permanent residence and ultimately citizenship. ${ }^{8}$ Although immigrants can gain full access to public benefits upon naturalization, only aliens "admitted for permanent residence" may naturalize as U.S. citizens. ${ }^{9}$ Aliens admitted on nonimmigrant visas only, including temporary workers, are not admitted as permanent residents and thus are not eligible for most public entitlements and are not eligible to naturalize. Current U.S. laws generally exclude not only

5 See Howard F. Chang, The Economic Analysis of Immigration Law, in Migration Theory: Talking ACross Disciplines 205, 221-22 (Caroline B. Brettell \& James F. Hollifield eds., 2000).

6 The National Research Council, for example, found that the average immigrant with more than a high-school education pays enough in taxes to produce a net fiscal benefit. National Research COUNCIL, THE New americans: Economic, Demographic, and Fiscal EfFects of Immigration 334 (James P. Smith \& Barry Edmonston eds., 1997) (hereinafter NRC]. In fact, once the NRC economists take the positive fiscal effect of the immigrant's descendants into account, they find that the average immigrant with a high-school education produces a net surplus of $\$ 51,000$, and the average immigrant with more than a high-school education produces a net surplus of $\$ 198,000$. Id. at 334 tbl.7.5 (reporting net present value of average fiscal impacts in 1996 dollars).

7 See Chang, supra note 5, at 222.

8 For a discussion of the gains that natives enjoy from immigration in the labor market, see NRC, supra note 6, at 135-53.

98 U.S.C. $\$ 1427$ (a) (2000). 
unauthorized immigrants but also nonimmigrants, including temporary workers, from a broad range of public benefits: With only narrow exceptions, these aliens are ineligible for "any Federal public benefit." 10 Thus, because guest-worker programs can give unskilled aliens access to our labor markets without necessarily providing full access to the benefits provided to citizens, these programs may allow the most liberal admissions policies possible for these aliens without imposing a fiscal burden on natives.

From the perspective of the interests of aliens, or from the perspective of liberal principles of social justice, however, these guest-worker programs are only second-best policies. The ideal policy, from these perspectives, may be legal permanent residence and access to citizenship and to all public benefits. This policy would be costly for natives, however, as the empirical evidence suggests that unskilled alien workers are likely to have a net negative fiscal impact if granted ready access to permanent residence and ultimately citizenship. ${ }^{11}$ Thus, the self-interest of natives is bound to impose constraints of political feasibility on the availability of immigrant visas. It may be politically infeasible to ask natives to set aside their collective self-interest in formulating our immigration laws. ${ }^{12}$ The U.S. government will likely continue to deem the promotion of the interests of natives the paramount objective of our immigration policies. ${ }^{13}$ Thus, as long as natives are limited in their willingness to bear these fiscal burdens, they are likely to restrict alien access to permanent residence, either through quantitative restrictions or through qualitative restrictions

108 U.S.C. § 1611(a) (2000).

11 Taking the positive fiscal effect of the immigrant's descendants into account, the National Research Council finds that the average immigrant with less than a high-school education imposes a net fiscal burden of $\$ 13,000$. NRC, supra note 6 , at 334 tbl.7.5 (reporting net present value of average fiscal impacts in 1996 dollars).

12 As Seidman observes, the limitations imposed by "bounded caring" are, "like it or not ... facts that exist in the world" and "unlikely to change more than marginally in the near future," so that any "real-world immigration policy must . . take account of these facts and work around them." Louis Michael Seidman, Fear and Loathing at the Border, in Justice IN IMMIGRATION 136, 140 (Warren F. Schwartz ed., 1995).

13 See, e.g., S. REP. NO. 98-62, at 3 (1983) ("[T]he paramount obligation of any nation's government, indeed the very reason for its existence and the justification for its power, is to promote the national interest-the long-term welfare of the majority of its citizens and their descendants."). 
that establish demanding criteria for immigrant visa eligibility. ${ }^{14}$

Some observers have described guest-worker programs without access to permanent residence as "more politically viable." 15 Thus, the Bush administration has shifted its energies toward a program for temporary workers, which it regards as "more acceptable politically." ${ }^{6}$ Recognizing the political controversy generated by proposals that would grant access to citizenship, Mexico has also emphasized an expanded guestworker program in its negotiations with the Bush administration and has been careful not to press the issue of citizenship. ${ }^{17}$

Under any politically feasible scenario, there will be many aliens who would like to gain access to the labor market but who are excluded by our immigration policies. Political constraints are likely to exclude many unskilled aliens from the U.S. labor market unless they are either willing to immigrate illegally or have access to guest-worker visas. Given these constraints on access to permanent residence, guest-worker programs may represent the only alternative to illegal immigration for aliens otherwise excluded from the U.S. labor market. $^{18}$ Under these

14 Cf. Ronald Brownstein, Residency at Core of Immigrant Debate, L.A. TIMES, July 29, 2001, at Al (discussing the debate over criteria and legislation that would allow immigrants to achieve permanent resident status).

15 Jonathan Peterson, Amnesty's the Road Bump in Debate on Immigration, L.A. Times, Aug. 9, 2001, at A12. Conservative Republicans like Senator Phil Gramm adamantly oppose any access to permanent residence for guest workers. Gramm has said that any such program would have to pass "over my cold, dead political body." Michelle Mittelstadt, Senators Call for Giving Residency to Immigrants, DALlas MoRNING NEwS, July 19,2001 , at $1 \mathrm{~A}$. In a recent Gallup poll, sixty-seven percent of respondents rejected easier access to U.S. citizenship for unauthorized immigrants, while only twenty-eight percent supported this proposal. Steve Sailer, Analysis: Why Bush Blundered on Immigrants, UPI, Sept. 10, 2001, available at LEXIS, News Library, UPI File.

16 Jonathan Peterson, Immigration Emphasis on Guest Visas, L.A. TimEs, Aug. 18, 2001, at A1.

17 By maintaining flexibility on this issue, Mexico seeks, as the Mexican foreign minister Jorge Castaneda puts it, "as many rights as possible, for as many Mexicans (in the United States) as possible, as soon as possible" within the constraints of political feasibility. Robert Collier, Momentum Grows to Legalize Migrants, S.F. ChroN., July 16,2001 , at A1. As one Mexican negotiator explained, "we . . have to be very realistic." Alfredo Corchado, Fox Pushes for a More Open Border, DALlas MORNING NEws, July 16, 2001, at 1A. Castaneda has explained that access to citizenship "is not something of huge significance to us." Sergio Munoz, Jorge Castaneda: Mexico's Man Abroad, L.A. TIMES, Aug. 12, 2001, at M3.

18 See Julian L. Simon, The Economic Consequences of Immigration 303 
circumstances, an expanded guest-worker program would represent an improvement not only for the aliens who thereby gain admission but also for natives.

In this essay, I argue in favor of a liberalized guest-worker program as a reform that would promote the welfare of both natives and aliens, compared to the politically feasible alternatives. In Part I, I propose a series of reforms that expands access to the U.S. labor market for unskilled alien workers without imposing an economic burden on natives. In Part II, I argue that although guest-worker programs do not comply with liberal ideals, they nevertheless represent an improvement over the alternative of exclusion, whether from the standpoint of the guest worker or from the perspective of cosmopolitan liberalism. In Part III, I conclude that given political constraints that make more ideal policies infeasible, liberals concerned with the welfare of aliens should support liberalized guest-worker programs.

\section{Guest-Worker Programs and the Interests of Natives}

Current programs for unskilled guest workers are subject to protectionist restrictions and are therefore little used. ${ }^{19}$ For example, both $\mathrm{H}-2 \mathrm{~A}$ visas for agricultural workers and $\mathrm{H}-2 \mathrm{~B}$ visas for other unskilled workers are subject to burdensome "labor certification" requirements. ${ }^{20}$ Furthermore, $\mathrm{H}-2 \mathrm{~B}$ visas are limited to 66,000 per year, ${ }^{21}$ and require workers to come "temporarily to the United States to perform . . . temporary service or labor." This "double requirement of "temporariness" requires the H-2B alien not only to enter temporarily, but also to fill a temporary

(1989) ("Being a temporary worker may well be inferior, and may even seem 'unfair,' compared to full admission as a legal immigrant, but this simply is not a realistic alternative; to compare a temporary worker program unfavorably against a non-existent alternative is either thoughtless or dishonest.").

19 See 8 U.S.C. \& 1101(a)(15)(H)(ii) (2000).

20 See id. § 1188(a)(1) (requiring the H-2A petitioner to show that "there are not sufficient workers who are able, willing, and qualified, and who will be available at the time and place needed" and that "the employment of the alien . . . will not adversely affect the wages and working conditions of workers in the United States"); 8 C.F.R. $\S$ 214.2(h)(6)(iv) (2001) (requiring a similar showing for the H-2B visa).

21 See 8 U.S.C. $\$ 1184(\mathrm{~g})(1)(\mathrm{B})(2000)$.

22 Id. § 1101(a)(15)(H)(ii)(b). 
job. ${ }^{23}$ The liberalization of these burdensome requirements could greatly increase use of these programs. ${ }^{24}$ We should expand access to these programs by either liberalizing or eliminating labor certification requirements, quotas, and restrictions on the duration of guest-worker employment or on their stays in the United States.

We should also remove restrictions on the types of employment that these guest workers may take, so that aliens are free to seek any job in the United States, and all sectors of the U.S. economy can benefit from hiring them. Recent discussions of an expanded guest-worker program envisioned liberalization beyond the agricultural sector to include the service sector of the U.S. economy, ${ }^{25}$ which would represent at least a step in the right direction. Better yet would be a program without any restrictions on the employment open to guest workers.

Many worthwhile reforms would be consistent with the economic interests of natives. The protection of the interests of natives does not require many of the restrictions currently imposed on guest workers. ${ }^{26}$ There is no need, for example, to restrict the alien's freedom to move from one employer to another or from one sector of the economy to another. Like immigration restrictions in general, restrictions on mobility between jobs are economically inefficient as well as unduly burdensome for the worker subject to the restriction. Freedom to leave an employer and to take employment elsewhere would give workers greater power to assert their rights against employers and thus prevent abuses, without destroying the gains from trade that natives enjoy

23 Thomas A. Aleinikoff et al., Immigration and Citizenship: Process and PoLICY 395 (4th ed. 1998).

24 Admissions under H-2B visas have remained below one-third of the quota limit in recent years, and admissions under H-2A visas have been similar. See id. at 393, 395 (noting that the demand for H-2B visas "would be much higher but for the double 'temporariness' requirement"); Alan O. Sykes, The Welfare Economics of Immigration Law, in JUSTICE IN IMMIGRATION, supra note 12, at 158, 189 (noting that "because of the transaction costs of obtaining a visa coupled with the limited certifications for labor shortages in the agricultural sector," employers often find that H-2A visas "are not worth the effort to procure").

25 See Diane Lindquist, Guest-Worker Plan Offers Jobs Beyond Farms, SAN DiEGO Union-Trib., Aug. 10, 2001, at A26.

26 Democrats in Congress have stressed that guest workers should enjoy the same rights in the workplace as citizens. See Jonathan Peterson, Democrats Up Ante to Reform Immigration, L.A. Times, Aug. 3, 2001, at A1. 
from employing alien workers. Thus, both Mexico and Democrats in Congress have urged that a reformed guest-worker policy include the freedom to change employers, ${ }^{27}$ and a proposal emerging from ongoing negotiations between the United States and Mexico could include at least this reform. ${ }^{28}$ We can also fortify the guest worker's incentives to complain about abuses with protections against employer retaliation for whistle-blowers or even bounties or other rewards for those who make meritorious claims that their employers are violating the rights of employees. ${ }^{29}$ At the same time, we must reduce or eliminate the protectionist barriers that we currently impose on employer sponsorship, such as labor certification. These liberalizing reforms are especially essential if we make the employee's visa more portable. Employers will be reluctant to invest much time or money in sponsoring a worker's visa if the worker is then free to leave to work for a competing employer who can thereby take a free ride on the sponsoring employer's investment in the visa.

Although the Bush administration has focused on negotiations with Mexico, the United States should avoid any discrimination among aliens based on national origin in an expanded guestworker program. Just as all sectors of the U.S. economy would benefit from a liberalized program, the economy would also gain by liberalizing access to its labor markets for all aliens regardless of nationality. We can enjoy the same economic benefits from workers from all nations, and to discriminate among workers based on national origin needlessly introduces costly distortions in the labor market. It is appropriate that Democrats in Congress have urged broad liberalization for aliens of all nationalities ${ }^{30}$ and

27 See Cheryl W. Thompson, Democrats to Offer Plan to Reform Immigration, WASH. Post, Aug. 2, 2001, at A2; Corchado, supra note 17, at $1 \mathrm{~A}$.

28 See Marcus Stern, New Immigration Plan Raises New Issues: U.S.-Mexican Strategy Goes Beyond Amnesty, Guest-Worker Program, SAN Diego Union-TriB., Aug. 12,2001 , at A1.

29 The AFL-CIO has urged whistle-blower protections and amnesty for unauthorized immigrants who complain about substandard working conditions or other violations. See Nancy Cleeland, AFL-CIO Calls for Amnesty for lllegal U.S. Workers, L.A. Times, Feb. 17, 2000, at A1; Frank Swoboda, Unions Reverse on Illegal Aliens, WASH. PoST, Feb. 17, 2000, at A1.

30 See Peterson, supra note 26, at A1; Thompson, supra note 27, at $\mathrm{A} 2$. 
that the Bush administration has seemed open to this suggestion. ${ }^{31}$

We might also allow unskilled guest workers to adjust their status to permanent residence without imposing a net burden on natives if appropriate conditions are met. ${ }^{32}$ In fact, as the Bush administration considers proposals to liberalize our immigration policies, it has discussed an expanded guest-worker program that would eventually allow guest workers to adjust their status to permanent residence and ultimately naturalize as citizens. Mexico has urged the United States to allow guest workers to remain permanently, and a proposal including some sort of access to permanent residence could eventually emerge from the negotiations between the two countries. ${ }^{33}$ The conditions for adjustment of status might include, for example, a sufficiently lengthy period of residence and employment as a guest worker without a criminal record, as well as payment of a sufficient amount in taxes over this period. ${ }^{34}$ Thus, admission as a guest worker need not entail permanent status as an alien. Empirical evidence indicates that the United States could allow even an unskilled immigrant to naturalize without generating a net fiscal burden if a sufficient period of alienage with only limited access to public benefits has passed. ${ }^{35}$

In reality, access to citizenship is a matter of degree. Aliens might be given the opportunity to naturalize after a short period of residence or only after a long period. We might demand a long work history and a large amount of taxes paid or impose less stringent requirements. A liberalized guest-worker program could choose any point along this continuum to satisfy critics concerned

31 See Edwin Chen \& Jonathan Peterson, Bush Hints at Broader Amnesty, L.A. TimEs, July 27, 2001, at A1.

32 See Chang, supra note 5, at 223.

33 See Stern, supra note 28, at A1.

34 See Laurie Goering, Bush Considering Green Card "Points," CHI. TRIB., Aug. 22, 2001, at 1; Eric Schmitt, No Agreement Yet with Mexico on Immigration Plan, N.Y. Times, Sept. 1, 2001, at A1.

35 The National Research Council found that once we take the positive fiscal effect of the immigrant's descendants into account, an immigrant with less than a high-school education imposes a net fiscal cost of only $\$ 13,000$ in net present value in 1996 dollars; see NRC, supra note 6, at 334; and that if the 1996 welfare legislation excludes immigrants from seven specified means-tested benefits for only their first five years in the United States, then the total fiscal impact of the average immigrant would improve by $\$ 8,000 ;$ see id. at 339 . 
about the fiscal impact of unskilled immigrants or the political impact of their naturalization and participation in the electorate. ${ }^{36}$

In any event, a guest-worker program would not produce a hereditary class of alien residents in the United States, because the Fourteenth Amendment of the U.S. Constitution gives U.S. citizenship to anyone born in the United States, including the children of nonimmigrants. ${ }^{37}$ Thus, guest-worker programs in the United States cannot create the type of caste society that they might in countries that do not provide this birthright citizenship. Furthermore, citizenship for the children of immigrants has proven to be consistent with the national economic interest, as the available evidence indicates that the descendants of even unskilled immigrants have a positive fiscal impact. ${ }^{38}$

To help deflect criticism that we are rewarding unauthorized immigrants for violating our immigration laws, ${ }^{39}$ we could refuse to count unauthorized work or residence as a factor in granting an alien status as either a guest worker or a permanent resident. We could continue to require employer sponsorship, which would not only ensure that the guest worker is gainfully employed (and thus likely to provide a net economic benefit to natives), but also tend as a practical matter to be a requirement most easily met by those aliens who are already employed in the United States as unauthorized immigrants. Thus, a guest-worker program could function in effect as a means for unauthorized immigrants to legalize their status without allowing them to derive any formal

36 See Sailer, supra note 15 (suggesting that the Republican Party resists legalization of unauthorized immigrants because it fears adding Hispanic voters to the electorate).

37 See U.S. CONST. amend. XIV, § 1 ("All persons born or naturalized in the United States, and subject to the jurisdiction thereof, are citizens of the United States and of the State wherein they reside.").

38 See NRC, supra note 6, at 329 ("[T] he present value of the descendants of a current immigrant . . . is always positive, regardless of the immigrant's age at arrival and education level.").

39 See Brownstein, supra note 14, at A26 ("[M] any conservatives say that creating a broad path toward permanent residency would reward illegal immigrants for breaking the law."); Thomas B. Edsall, Amnesty Proposal Is Huge Gamble for Bush, WASH. POST, July 17, 2001, at A2 (quoting Sen. Phil Gramm as calling amnesty for unauthorized immigrants "'very bad policy' that 'rewards lawlessness"”); Peterson, supra note 15, at A12 (quoting Rep. Tom Tancredo as criticizing amnesty for unauthorized immigrants as "rewarding someone for breaking the law"). 
benefit from their unauthorized residence or employment. Unlike an amnesty program, which would only legalize the stock of unauthorized immigrants already here, a guest-worker program could also legalize some of the flow of unauthorized immigrants into the United States, thereby providing a more permanent solution to the problem of illegal immigration. These workers would gain from having a legal alternative to illegal entry and life as an unauthorized immigrant, which leaves them vulnerable to deportation by the government and to abuse by employers.

To help deflect criticism that any legalization of unauthorized immigrants is unfair to those waiting patiently for visas to immigrate legally, ${ }^{40}$ a guest-worker program could give priority to qualified applicants who have also applied for immigration visas subject to backlogs. Such a program would have the advantage of allowing those who are already entitled to permanent residence to gain admission to the United States and its labor market sooner. This reform would benefit not only the alien granted quicker admission but also natives, who derive greater fiscal benefits from the alien's earlier admission. The age of an immigrant at the time of entry proves to be an important determinant of the total fiscal impact of that immigrant. In general, the younger the immigrant at the time of entry, the more working years the immigrant can spend in the United States, the more tax revenues the immigrant will contribute to public coffers prior to retirement, and the more positive the immigrant's overall fiscal impact. ${ }^{41}$ Thus, a guestworker program that allows immigrants waiting in backlogs to enter the United States sooner also allows natives to enjoy the economic benefits of more of each immigrant worker's productive years and improves the total fiscal impact of each of those immigrants.

\section{Liberal Ideals, the Interests of Aliens, and the Second-Best}

Once we lift restrictions on the duration of a guest worker's residence and employment in the United States, however, the program raises the prospect of de facto permanent residents with

40 See Mittelstadt, supra note 15, at 1A (quoting Rep. Tom Tancredo as calling amnesty for unauthorized immigrants "a kick in the teeth to the thousands of individuals across the world who are legally attempting to enter the United States").

41 See NRC, supra note 6, at 328 fig.7.10. 
only restricted access to citizenship. ${ }^{42}$ Liberal objections to this prospect account for at least some of the political resistance to expansion of these guest-worker programs. James Woodward objects that " $[t]$ he creation of a class of permanent residents who are restricted from becoming citizens (if they should wish to do so) or any similar system of differential status among a state's permanent inhabitants is fundamentally incompatible with liberal egalitarian ideals. ${ }^{, 43}$

As Joseph Carens and others have argued, however, the exclusion of aliens is also incompatible with these ideals. Consider the liberal theory of justice developed by John Rawls, who asks what principles people would choose behind a "veil of ignorance." 44 In this "original position," people know nothing about their own personal circumstances or traits and thus "do not know how the various alternatives will affect their own particular case and they are obliged to evaluate principles solely on the basis of general considerations." ${ }^{45}$ This condition ensures that "the parties are fairly situated and treated equally as moral persons." ${ }^{.46}$ Using Rawls's theory, Carens addresses the issue of immigration restrictions as a question of social justice. ${ }^{47}$ In seeking a justification for the exclusion of aliens, "we don't want to be biased by self-interested or partisan considerations" and instead "can take it as a basic presupposition that we should treat all human beings, not just members of our own society, as free and equal moral persons.." ${ }^{48}$ Carens identifies this premise as a basic

42 See Munoz, supra note 17, at M3.

43 James Woodward, Commentary: Liberalism and Migration, in FREE MOVEMENT: Ethical Issues in the Transnational Migration of PeOple and of Money 59, 82 (Brian Barry \& Robert E. Goodin eds., 1992) [hereinafter FrEE MOVEMENT]. The communitarian Michael Walzer adopts a similar position. See MiChaEL Walzer, SPHERES OF JUSTICE: A DEFENSE OF PLURALISM AND EQUALITY 56-61(1983) (arguing that guest-worker programs are inconsistent with political justice in a democratic state).

44 See JOHN RAWLS, A THEORY OF JUSTICE 136-42 (1971).

45 Id. at 136-37; see id. at 141 ("If a knowledge of particulars is allowed, then the outcome is biased by arbitrary contingencies.").

46 Id. at 141.

47 See Joseph H. Carens, Aliens and Citizens: The Case for Open Borders, 49 REv. POL. 251, 255 (1987).

$48 \mathrm{Id}$. at 256. 
feature of all liberal political theories,${ }^{49}$ concluding that we should "take a global, not national, view of the original position." 50

If we begin with equal concern for all persons, then immigration barriers are morally suspect and demand justification. All our immigration restrictions discriminate against individuals based on their alienage, which in turn derives from immutable characteristics, such as the geographic location of their birth (that is, national origin) and other circumstances of birth such as parentage. ${ }^{51}$ National origin appears to be a trait that Rawls would deem "arbitrary from a moral point of view." 52 Carens concludes that we cannot justify restrictions "on the grounds that those born in a given territory or born of parents who were citizens were more entitled to the benefits of citizenship than those born elsewhere or of alien parents." 53 Nor can we justify restrictions "on the grounds that immigration would reduce the economic well-being of current citizens." ${ }^{\text {"54 }}$ Similarly, in a utilitarian calculation of global welfare, "current citizens would enjoy no privileged position." Carens and others conclude from these cosmopolitan liberal premises that "we have an obligation to open our borders much more fully than we do now." 56

49 See id. at 265 (claiming that "our social institutions and public policies must respect all human beings as moral persons" which "entails recognition ... of the freedom and equality of every human being"); id. at 269 ("No moral argument will seem acceptable ... if it directly challenges the assumption of the equal moral worth of all individuals.").

50 Id. at 256.

51 See U.S. ConsT. amend. XIV, § 1 ("All persons born . . . in the United States, and subject to the jurisdiction thereof, are citizens of the United States . ..."); 8 U.S.C. $\S$ 1401 (1994) (setting forth categories of "citizens of the United States at birth").

52 RAWLS, supra note 44 , at 72.

53 Carens, supra note 47 , at 261.

54 Id. at 262.

55 Id. at 263 ("[T] assumption that everyone is to count for one and no one for more than one when utility is calculated.").

56 Id. at 270. Carens condemns immigration restrictions: "Like feudal barriers to mobility, they protect unjust privilege." Id. Similarly, Bruce Ackerman concludes that immigration barriers are inconsistent with liberal principles: "I cannot justify my power to exclude you without destroying my own claim to membership in an ideal liberal state." Bruce A. Ackerman, Social Justice in the Liberal State 93 (1980); see Roger Nett, The Civil Right We Are Not Ready For: The Right of Free Movement of People on the Face of the Earth, 81 ETHICs 212, 224 (1971) ("May we expect the lesson 
Political realities, however, may prevent the adoption of the immigration policies implied by these liberal ideals. If political realities require us to choose between two alternatives, the exclusion of an alien and the alien's admission as a guest worker, both of which deviate from liberal egalitarian ideals, then how can Woodward justify the choice that inflicts the greater harm on the alien as well as on natives? ${ }^{57}$ Ironically, Woodward himself notes that if we act against a "background of non-ideal institutions and behaviour" in a world "in which large numbers of people and institutions fail to do what justice requires," we may "acquire obligations which are different from those [we] would acquire under more perfectly just institutional arrangements." ${ }^{\text {"5 }}$ As Woodward states the theory of the second-best:

It is not in general a defensible moral principle that if it is obligatory (or even a good thing) to do $\mathrm{P}$ under ideal, utopian circumstances, then it is also obligatory (or even a good thing) to do $\mathrm{P}$ under the actual circumstances, no matter how far they may differ from the ideal. ${ }^{59}$

Robert Goodin notes that " $[\mathrm{t}]$ here is much to be said for the realist argument" that insists upon "the importance of not making a fetish of moral ideals," because "doing the best you can in an imperfect world may well require you to compromise any (indeed, all) of your moral ideals" and a "[f]ailure to take due account of the probable reactions of others can ... have consequences that are truly catastrophic.",60

Although Woodward advances realist claims in defense of immigration restrictions, they could more plausibly justify

which the Negro has taught his fellow Americans about denial of fair opportunities to be repeated on a broader scale, with the underprivileged of the earth demanding 'desegregation' of nation states?").

57 Carens agrees that to admit guest workers without "giving them the opportunity to become citizens" is "incompatible with our liberal democratic principles," but adds that "so is a restrictive policy on immigration." Carens, supra note 47, at 268.

58 Woodward, supra note 43 , at 78 .

59 Id. at 77; see Joseph H. Carens, Migration and Morality: A Liberal Egalitarian Perspective, in FREe MOVEMENT, supra note 43, at 25, 45 ("Ideals do not always translate directly into prescriptions for practice because of the second-best problems familiar from economic theory which have their analogue in moral theory.").

60 Robert E. Goodin, Commentary: The Political Realism of Free Movement, in FREE MOVEMENT, supra note 43, at 248, 255. 
restrictions on alien access to public benefits and to citizenship. Indeed, Woodward himself notes that "it is far from obvious that it would be wrong . . . to limit eligibility for social welfare programmes to citizens or long-term residents, if failure to do so would jeopardize the continued existence of such programmes." $" 61$ We might say the same about restrictions on alien access to public benefits and citizenship if these restrictions are necessary to make politically feasible the alien's access to our labor market and the alien's admission in the first place.

After all, exclusion offers no obvious advantages over a guestworker program, whether from the standpoint of political justice or from the perspective of the interests of the alien worker. ${ }^{62}$ Exclusion discriminates against the alien just as surely as guestworker status does. Like admission under a guest-worker policy, exclusion is an exercise of the state's authority over the alien, and neither policy offers the alien any role in the formulation of that policy through participation in the U.S. political system. If we must choose between these two forms of discrimination, then we should opt for the guest-worker program, because complete exclusion from the United States is the more sweeping form of discrimination and inflicts the greater harm on the alien. The guest-worker program at least offers the alien a choice, and by choosing to come as a guest worker, the alien reveals a preference for guest-worker status over the alternative of exclusion. ${ }^{63}$

These second-best arguments require us to rank two non-ideal

61 Woodward, supra note 43 , at 79.

62 See Howard F. Chang, Liberalized Immigration as Free Trade: Economic Welfare and the Optimal Immigration Policy, 145 U. PA. L. REV. 1147, 1192-94 (1997) (arguing that a guest-worker program is better than a policy of exclusion).

63 See Simon, supra note 18, at 303 ("Participating in the program must be better for at least some persons than not participating, or else there would be no participants in the program."). There seems little reason to second-guess the alien regarding the decision to become a guest-worker. See id. at 310 (arguing that if we wish to show respect for the alien's "human dignity," then "giving people the choice of whether they do or do not wish to serve as guestworkers seems to be more dignified than deciding for them that serving as guestworkers would not be good for them"). While paternalistic regulations may be appropriate when we have evidence that individuals make irrational choices, it is difficult to declare the decision to become a guest-worker irrational, given the alternatives that these aliens face. See Seidman, supra note 12, at 143 ("Why should anyone believe that a guest worker is 'exploited' when he receives higher wages and more protection in the program than he would receive if he remained in his home country?'). 
alternatives, both of which fall short of our liberal ideals. ${ }^{64}$ In this regard, teleological moral theories have an advantage over deontological theories. Under a teleological theory, "those institutions and acts are right which of the available alternatives produce the most good." 65 Once we specify the good, then a teleological theory can provide a complete ranking of all alternatives, including non-ideal alternatives. ${ }^{66}$ Deontological theories, which do not maximize a good specified in advance, ${ }^{67}$ may not readily provide a ranking of non-ideal alternatives. ${ }^{68}$

We might, for example, specify the good as an appropriate measure of social welfare, one based on the satisfaction of preferences but excluding those preferences that violate liberal principles of equality. Ronald Dworkin, for example, has proposed such a teleological theory. ${ }^{69}$ If we apply this type of consequentialism and adopt a cosmopolitan perspective, then a guest-worker program represents the lesser of two evils when compared with the alternative of exclusion. To exclude aliens from our labor markets not only decreases global wealth but also worsens its distribution, whereas a guest-worker program would improve social welfare on both counts. ${ }^{70}$

From this cosmopolitan perspective, liberal opposition to guest-worker policies is misguided, because the alternative of exclusion raises even worse moral problems. Discriminating

64 See Simon, supra note 18, at 310 ("Compared to a beautiful world of no borders and perfect freedom to live with full rights wherever one likes, having both citizens and non-citizens within a country may seem undesirable. But compared to a world in which every country controls who may enter . . the comparison may seem quite different.").

65 RAWLS, supra note 44, at 24.

66 For definitions of a "complete" ordering, see ROBIN BOADWAY \& NEIL BRUCE, Welfare ECONOMics 34 (1984) and JoHN vON NEUMANN \& OSKar MORGENSTERN, THEORY OF GAMES AND ECONOMIC BEHAVIOR 26 (3d ed. 1953).

67 See RAWLS, supra note 44 , at 30.

68 See id. at 303 (suggesting that "we may be able to find no satisfactory answer at all" in "instances of nonideal theory").

69 See Ronald Dworkin, Taking Rights Seriously 234-38 (1977). I have outlined a similar theory, which I call "liberal consequentialism." Howard F. Chang, A Liberal Theory of Social Welfare: Fairness, Utility, and the Pareto Principle, 110 YALE L.J. 173, 195-96 (2000).

70 See Chang, supra note 5, at 207-08; Bob Hamilton \& John Whalley, Efficiency and Distributional Implications of Global Restrictions on Labour Mobility, $14 \mathrm{~J}$. DEv. ECON. 61, 70-74 (1984). 
against aliens in the allocation of employment opportunities in the United States may benefit some U.S. workers, but only at the expense of employers who must bear higher labor costs, the consumers who must pay higher prices for goods and services, and the alien workers who are confined to labor markets where they earn lower wages than those prevailing in the U.S. labor market and are thus even worse off than the beneficiaries of the policy of exclusion. Thus, the employment discrimination against aliens implied by a policy of exclusion is difficult to justify from a cosmopolitan perspective because its primary victims are poorer than the workers who are privileged by this discriminatory regime. If guest-worker programs make us uneasy, then exclusion should only make us more so, because it keeps alien workers in a state of poverty that they would prefer to escape as guest workers. In this sense, the liberal who invokes ideal principles to condemn guestworker programs while favoring the alternative of exclusion is vulnerable to the charge of "superstitious "rule worship," that is, "the charge of heartlessness, in his apparently preferring abstract conformity to a rule to the prevention of avoidable human suffering.",71

\section{III.Conclusion}

From a welfare perspective, it is harmful public policy to exclude the alien worker from not only U.S. citizenship but also our labor market, given that admission as a guest worker would make both the alien worker and U.S. natives better off. The employment discrimination implied by a policy of exclusion is difficult to justify whether we adopt the cosmopolitan perspective or instead embrace less egalitarian liberal ideals and favor the interests of natives over those of aliens. Considerations of both global economic welfare and national economic welfare militate in favor of liberalized alien access to our labor markets. While the employment discrimination against aliens implied by our immigration restrictions remains difficult to justify, some discrimination against unskilled aliens in the distribution of public benefits and in access to citizenship may serve the interests of natives.

71 J.J.C. Smart, An Outline of a System of Utilitarian Ethics, in J.J.C. SMART \& BERNARD Williams, UtilitaRIANISM: For AND AGAinst 3, 6 (1973). 
The cosmopolitan liberal would prefer that aliens have access to both our labor market and ready access to public benefits and citizenship. As a matter of political reality, however, natives are unlikely to admit aliens under those generous conditions in the numbers that cosmopolitan ideals would require, given the fiscal burden that those liberal policies would entail. Given this constraint of political feasibility, cosmopolitan liberals face a trade-off: significantly liberalized access to our labor markets for unskilled alien workers will likely require some restrictions in access to public benefits and citizenship to have a realistic chance of enactment. From a consequentialist perspective that extends equal concern to aliens and natives, guest-worker programs are less unjust than the status quo alternative of exclusion. Reforms that reduce employment discrimination against aliens should prove feasible, even while eliminating all discrimination against aliens remains an unrealistic ideal. Therefore, cosmopolitan liberals should support liberalizing reforms that include guest-worker programs, even while seeking the broadest rights possible for aliens within the constraints of political feasibility. While it would be a mistake to pretend that this compromise is ideal from a liberal egalitarian perspective, it would also be a mistake to sacrifice worthwhile reforms because they fall short of the ideal. 
